\title{
Komunikasi Anti Hoax: Upaya LDNU dalam Membangun Persepsi Masyarakat untuk Mencegah Berita Hoax Melalui Media Massa
}

\section{(Anti Hoax Communication: LDNU's Efforts in Building Public Perception to Prevent Hoax News Through Mass Media)}

\author{
M. Nasrullah Jamaluddin Arrozi \\ Program Pascasarjana Komunikasi dan Penyiaran Islam, Universitas Islam Negeri Walisongo, Indonesia \\ email: nasrullarrozi@gmail.com
}

\begin{tabular}{ccc}
\hline First received: & Revised: & Final Accepted: \\
7 july 2021 & 2 September 2021 & 11 November 2021 \\
\hline
\end{tabular}

\begin{abstract}
This research is aimed to describe the institutional changes and advances in technology informasions and public perceptions. Information or news is the medium that every person needs in order to access knowledge through the internet network without any territorial and time limits. The role of an institution is important in building an order of public understanding in order to understand news content without being indicated by hoaxes. This virtual room is the fastest way to access online news, because most people already have internet-based mobile phones with additional features that are also needed by the public. Hoax or fake news is informations that has been set to attract mass opinion for certain interests. This type of hoax is not only news content but also photos, videos and other images that can be processed into fake news. The data source of this research is the result of movement in NU Da'wa Institution through news sites, social media Facebook, and in the field. Methods of data collection are observation and documentation. The results showed that fake news attacks greatly affected the community. Communication ethics bas been done by the institution and minimized by the existence of lies. Of course, this effort is done through building public perceptions as one of the keys to preventing hoaxes (fake news) which has eroded people's mindset. The principle of communication bas provided a channel for channeling the content of messages that must be conveyed factually without any indication of lies in it. Principles and ethics that are based on knowledge and science become communication activities to prevent hoaxes (fake news).
\end{abstract}

Keywords : Communication; Hoax; Building Public Perception; Preventing Hoax News; Mass Media.

\begin{abstract}
ABSTRAK
Penelitian ini merupakan usaha yang memiliki tujuan untuk menggambarkan perubahan dan kemajuan teknologi informasi secara ke-Lembagaan dan persepsi masyarakat. Informasi atau berita menjadi medium yang dibutuhkan setiap personal untuk mengkases pengetahuan melalui jejaring internet tanpa ada batas teritori dan waktu. Peran sebuah lembaga menjadi penting untuk membangun tatanan pemahaman masyarakat agar memahami isi berita tanpa terindikasi hoax. Ruang maya inilah jalur tercepat mengakses berita online, karena sebagian besar masyarakat sudah memiliki handphone berbasis internet dengan tambahan vitur yang sangat dibutuhkan juga oleh masyarakat. Hoax atau berita bohong merupakan informasi yang telah di setting agar menarik opini massa demi kepentingan tertentu. Jenis hoax tidak hanya isi berita namun foto, video, dan gambar lainnya dapat diolah menjadi berita bohong. Sumber data penelitian ini adalah hasil pergerakan Lembaga Dakwah NU melalui situs berita, media sosial Instagram. Metode pengumpulan data menggunakaan tinjauan literatur. Hasil penelitian menunjukkan bahwa terjangan berita bohong sangat mempengaruhi masyarakat. Etika komunikasi telah dikerjakan oleh lembaga dan diminimalisir dengan adanya berita bohong. Tentunya upaya ini melalui pembangunan persepsi masyarakat sebagai salah satu kunci pencegahan hoax (berita bohong) yang selama ini masih menggerus pola pikir masyarkat. Prinsip komunikasi telah memberikan jalur dalam menyalurkan isi pesan yang harus disampaikan secara faktual tanpa indikasi kebohongan didalamnya. Prinsip dan etika yang berlandaskan pengetahuan dan keilmuan menjadi aktivitas komunikasi untuk mencegah hoax (berita bohong).
\end{abstract}


Kata kunci : Komunikasi; Hoax; Membangun Persepsi Masyarakat; Mencegah Berita Hoax; Media Massa.

\section{PENDAHULUAN}

Komunikasi menjadi peran dasar dalam kehidupan makhluk-Nya, interaksi antar sesama juga kebutuhan yang tidak dapat di nafikkan. Era milenial interkasi tidak hanya tatap muka dan bersanding sua saling mengisi cerita satu sama lain. Teknologi informasi merubah kebahagian yang tersanding menjadi isi cerita melalui surat maya. Isi cerita yang tidak berambisi memiliki kepentingan dan pengaruhnya. Berkumpul dan bersenda gurau tanpa memandang identitas pemiliknya menjadikan isi berita layaknya pengetahuan sangat berharga. Profesi guru, tukang becak, pegawai kelurahan, hingga pengusaha saling menguatkan informasi sesuai pengalaman masing-masing. Gairah yang sama mendorong persepsi agar terjalin komunikasi menjadi padu tidak rusak termakan oleh kepalsuan. Berita bohong (boax) datang melalui berita maya via online juga tidak melihat siapa pembacanya. Namun, menggiring masyarkat agar dapat membenci satu sama lain atau bahkan saudaranya sendiri.

Jika pada konteks pandangan komunikasi, aktivitas ini selalu dilakukan oleh antar manusia, sehingga dalam proses tersebut manusia sangat mendambakan komunikasi yang efektif, lancar, dan mengandung informasi yang positif. Supaya tidak menjurus ke konflik dan kerusakan (Ridwan, 2016). Dimensi ini menjadi pertaruhan antara kebanaran dan kebohongan. Esensi komunikasi menjadi peran aktif menuju upaya antisipasi masyarakat terhadap berita bohong.

Dilansir dari Kementerian Komunikasi dan Informatika dengan melibatkan penyelenggara platform digital untuk mencegah penyebaranberita bohong. Hingga 5 Mei 2020 hasil pantauan Tim AIS Ditjen Aptika, menunjukkan 1.401 konten hoaks dan informasi tidak sesuai selama Covid-19 beredar di masyarakat (Kominfo, 2020). Artinya penyebaran hoax masih memiliki sifat militansi yang sangat tinggi. Dengan memanfaatkan isu yang tidak sesuai dan membuat berita bohong kehidupan masyarkat sangat bersentuhan lang sung melalui gadget mereka.

Kini hoax sangat cepat penyebarannya melalui media online. Terdapat hasil penelitian dari Mastel (2017) menjelaskan bahwa saluran yang digunakan untuk menyebaran berita boax diantaranya situs web $34,90 \%$, aplikasi chatting (whatsaap, line, telegram) sebesar $62,80 \%$, selanjutnya ada instagram, twiter, path yang menjadi penyalur terbanyak mencapai $92,40 \%$. Tidak hanya itu tahun 2016 Kementerian Komunikasi dan Informatika ada sebanyak 800 ribu situs di Indonesia yang terindikasi sebagai penyalur utama berita bohong (Juditha, 2018).

Pertengahan 2014 menjadi awal kemunculan hoax melalui pergerkan yang berangsur meningkat banyak sekali berita bohong yang terkuak. Frekuensi timbulnya berita yang diadaadakan melalui media kini terjadi pada awal 2016 lalu. Dengan tingginya intensitas berita bohong ini banyak masyarakat beranggapan bahwa kejujuran dan kejernihan berpikir telah hilang, alias curiga dan ketidak percayaan menjadi lumrah (Ali, 2017).

Tidak hanya itu, masyarakat mestinya telah sadar dengan kondisi semacam ini, akan tetapi faktor pengelolaan berita masih minim secara terstruktur. Sejalan dengan keadaan ini kita tidak bisa menganggap sepele berita bohong ini. Sebagai contoh akibat tersebarnya berita bohong pada dekade 1930-an sampai dengan 1940-an terjadi pembantaian hebat kaum Yahudi di Jerman, dengan pemicu utamanya adalah pasukan nazi-Hitler menyebarkan berita bohong bahwa faktor utama penyebab kekalahan rezim fasis nazi-hitler adalah kaumYahudi. Mereka beranggapan bahwa dekadensi bangsa Jerman akibat dari orang-orang Yahudi yang rakus dan tidak beradab. Sampai sekarang bangsa Jerman dihantui rasa bersalah karena termakan oleh penyabaran berita bohong dan hasil dari propaganda tersebut jutaan orang Yahudi di Jerman meregang nyawa sia-sia (Ali, 2017).

Charles Horton Cooley dalam Mukti Ali memberikan gambaran tentang komuikasi, 
bahwa mekanisme munculnya interaksi antar sesama yang menjadikan seseorang lebih maju melalui simbol dan alat yang menjamin informasi dapat disimpan oleh dimensi ruang dan waktu (Ali, 2017). Di Indonesia sendiri berita bohong atau yang disebut hoax sudah merajalela ketika suasana pemilu, pilkada, dan pemilihan wakil rakyat. Semenjak itu satu dengan yang lain saling menjatuhkan dan mencari sisi kelam agar kemenangan memihak daripadanya. Tentunya pengaruh ini sangat merugikan masyarakat dan semua pihak. Hasil berita bohong yang merusak berbagai hubungan antar kalangan, fasilitas umum bahkan melayangnya nyawa seseorang.

Ketika mengatas namakan kebebasan para pengguna internet dan media sosial khususnya banyak netizen yang merasa mempunyai hak penuh terhadap akun pribadi miliknya. Mereka merasa sah-sah saja untuk menggunggah tulisan, gambar atau video apapun ke dalam akunnya. Meskipun terkadang mereka tidak sadar bahwa apa yang mereka unggah tersebut bisa saja melanggar etika berkomunikasi dalam media sosial. Kegaduhan yang terjadi di media sosial dinilai bisa merambat ke dunia nyata jika tidak segera diatasi. Perbincangan yang terdapat di media sosial berpotensi mengkonstruksi pemahaman publik mengenai suatu hal dalam kehidupan masyarakat. Kegaduhan di media sosial dapat berdampak dalam kehidupan riil karena media sosial ini juga membentuk konstruksi pemaknaan tentang asumsi sosial kita.

Presiden Joko Widodo juga menjelaskan hoax adalah efek dari keterbukaan sosial baik online atau tidak yang harus kita hadapi. Presiden juga meminta agar penyebaran berita hoax segera dihentikan karena dapat menimbulkan fitnah dan memecah belah bangsa melalui media sosial. (Widodo, 2017). Wiranto selaku Koordinator Bidang Politik, Hukum, dan Keamanan mengatakan, masyarakat sudah pasti akan merasa dirugikan dengan adanya berita bohong ini, masyarakat akan menjadi bingung mana berita benar mana berita yang salah. Titik kelemahan ini menjadi sebuah kesempatan bagi para oknum untuk memanfaatkan situasi sehingga timbul rasa kebencian yang mudah dicerna pada saat situasi tersebut. Tentunya perpecahan, kerusakan, kegaduhan, kenyamanan masyarakat akan terganggu (Tarigan, 2017).

Ketidakbenaran informasi yang tersebar di media sosial seringkali terdapat sentimen identitas yang bermuara pada hujatan dan ujaran kebencian (Juliswara, 2017). Dalam merespon persoalan semacam itu, seluruh elemen masyarakat diharapkan dapat merumuskan konsep yang sesuai dalam mengantisipasi terjadinya kegaduhan di media sosial. Di sisi lain, persoalan mengatasi kegaduhan di media sosial melalui penegakan hukum juga tidak perlu merusak semangat kebebasan berekspresi dalam sistem yang demokratis. Artinya perlawanan hoax dibangun melalui prinsip kebersamaan dan terstruktur. Sehingga unsur demokrasi tetap terjaga tanpa ada perselisihan.

Membuat konsep komunikasi anti hoax perlu adanya dukungan secara strategi. Melalui pengembangan pola pikir dewasa dalam meenggunakan media sosial tentuya harus disesuaikan dengan budaya kejujuran dan ranah antisipasi penerimaan berita bohong ini. Peran komunikasi lembaga yang terstruktur untuk membekali masyarakat agar dapat mengantisipasi hoax sangatlah penting. Salah satu dari cara ini adalah membangun masyarakat yang lebih cerdas dan memiliki nilai budi pekerti yang luhur tentunya dalam aspek penggunaan media sosial. Dari sinilah terdapat pembahasan yang akan mengulas salah satu lembaga yang mengawal masyarakat agar tidak terpengaruh oleh berita hoax. Tentang bagaimana upaya Lembaga Dakwah NU dalam mencegah berita hoax.

\section{METODE PENELITIAN}

Penelitian ini menggunakan pendekatan kualitatif yang bertujuan untuk mengeksplorasi secara mendalam melalui fenomena hoax. Penelitian kualitaif ini berisi tinjauan literatur, konsepkonsep teoritis yang berhubungan dengan masalah penelitian yakni masalah penyebaran berita boax dan penggunaan media sosial dalam upaya membangun persepsi masyarakat kemudian dilanjutkan dengan observasi dan analisis wacana. Tinjauan literatur khususnya dengan 
metaanalisis literatur yaitu teknik khusus yang digunakan untuk membuat tinjauan integratif atau tinjauan metodologi. Mengenai metaanalisis literatur ini menjadikan beberapa langkah penelitian 1. Mencari hasil karya tulis yang potensial yang dapat menjadi rujukan penilitian ini. 2. Mengolah kriteria hasil temuan agar relevansi dengan permasalahan. 3. Menarik kesimpulan dari data yang sudah diolah.

Selain metaanalisis metode yang digunakan adalah observasi dan wacana yaitu melihat dan menelaah pergerakan lembaga dakwah NU dalam memberikan pemahaman kepada masyarakat terhadap berita hoax. Karena baik berita hoax atau tidak isi berita akan menjadi pengaruh yang kuat dalam kehidupan masyarakat. Langkah awal adalah mengidentifikasi artikel yang relevan untuk menunjang literatur terkait dengan komunikasi dan hoax. Tentunya artikel yang diprioritaskan yang terbit pada tahun 2000 - 2020. Selanjutnya dari sumber yang telah diterima maka akan diperiksa lebih lanjut guna menjaga relevansi dalam pembahasan ini. Referensi yang dipakai adalah artikel, jurnal dan buku yang memuat permasalahan tentang boax.

\section{HASIL PENELITIAN DAN PEMBAHASAN}

\section{Komunikasi anti hoax}

Deddy Mulyana menyertakan pernyataan Harold Laswell dalam mendefinisikan komunikasi dengan menggambarkan komunikasi sebagai pertanyaan-pertanyaan who says, what and with channel to whom with what effect, (siapa yang mengatakan, apa dengan saluran apa, kepada siapa, dengan pengaruh bagaimana) (Mulyana, 2010). Tidak hanya siapa pemberi pesan dan siapa penerima pesan akan tetapi dampak dari pesan itu sendiri yang menjadi pengaruh kuat dalam merubah situasi khalayak.

Penerapan komunikasi merupakan proses fundamental, setiap aktivitas dalam lingkup individu pribadi, sosial maupun pekerjaan tidak bisa lepas dari komunikasi. Karir semua pihak sudah banyak yang menuntut untuk memahami proses kumunikasi, mengembangkan strategi komunikasi yang efektif termasuk menjalin hubungan dengan orang lain serta menyajikan gagasan melalui beragam saluran media komunikasi.

Berbagai saluran komunikasi sudah merajai dunia elektronik, banyak saluran menjadi berita cepat sampai kepada penerima. Asumsi yang terjadi semakin cepat pula pemaksaan kepercayaan tanpa menguji kebenaran berita yang diterima. Howard dan Parks menjelaskan pembagian media sosial menjadi 3 yaitu: Produksi alat, sarana informasi dan perencanaan isi media berupa pesan pribadi, berita, gagasan serta produk budaya yang membentuk digital. Pengelolaan pesan melalui personal, organisasi, dan industri. Sehingga media sosial memiliki kemampuan yang dapat menghilangkan batasan ruang dan waktu, secara dimensional geografis dan teritori. Percepatan penyaluran arus informasi semakin cepat sampai kepada masyarakat yang tidak pernah terbayangkan sebelumnya (Alif, Hardian, Kurniawan, Triartanto, \& Suriyanto, 2018).

Berperilaku sehari-hari merupakan upaya etika yang dilakukan secara silih berganti bahkan disamakan dengan moral dan akhlaq. Jika etika adalah bentuk pedoman terhadap prilaku manusia yang didasari oleh ukuran akal manusia, maka moral memiliki makna yang tidak berbeda. Moral diambil dari bahasa latin "mores" kata jamak dari "mos" yang berarti adat kebiasaan (Ya'qub, 1998). Kebiasaan menggunakan media sosial untuk menyalurkan berita dan informasi secara terbuka, tentunya penerima berita benar-benar terpelajari dengan pemahaman memaknai isi berita. Fenomena hoax patut menjadi perhatian bagi semua kalangan. Upaya pencegahan terus dilakukan tanpa memandang siapa yang mempersiapkan berita bohong ini. Baik pemerintah dan swadaya masyarakat terus mengantisipasi adanya berita bohong. khususnya melalu facebook dan WhatsApp yang mendominasi penggunaan media sosial di Indonesia karena dampaknya yang menyebabkan merosotnya kemampuan analisa seseorang sehingga mudah menyinggung emosi negatif, seperti rasa marah, ketakutan, kecewa dan 
sedih. Emosi yang dominan cenderung mendorong orang untuk merespons cepat tanpa berpikir panjang.

Keberadaan media sosial sudah menjadi hal biasa bagi kehidupan era modern ini. Karena saat ini pemasaran smartphone mendominasi semua kalangan berdasarkan kebutuhan pengguna dan pemanfaatan pengembangan teknologi internet baik kebutuhan personal kebutuhan lembaga sebagai penunjang pekerjaan. Dari hasil pengamatan menyatakan bahwa setiap personal memiliki banyak akun media sosial. Hal ini menunjukkan bahwa begitu mudahnya pengguna dalam mengakses berbagai vitur yang disediakan oleh gadget-nya. Sehingga semua pengguna dapat berpastisipasi dalam membangun jejaring sosialnya melalui online, baik isi pesan dengan bentuk blog, forum grup, ataupun dalam bentuk komunitas secara online.

Buente dan Robbin, ketika mereka melaksanakan studi investigasi tentang saluran informasi melalui internet kepada warga Amerika antara Maret 2000 hingga November 2004 (W \& A, 2008). Hasil riset itu menunjukkan bahwa terdapat empat dimensi dalam penggunaan internet yaitu informasi (information utility), kesenangan (leisure/fun activities), komunikasi (communication), dan transaksi (transaction). Investigasi ini menggambarkan bahwa alur pemakaian media sosial di lingkungan civitas akademik Universitas Presiden meliputi empat dimensi sesuai dengan hasil temuan Buente dan Robbin. Hal ini menunjukkan ada perilaku pengguna yang positif bilamana aktivitas yang dilakukan pengguna sesuai dengan lingkungan kampus, seingga pemakaian internet atau secara spesifik media sosial harus disikapi secara bijak. Penyebaran berita bohong yang marak terjadi ini jika dikaitkan dengan etika pada internet adalah penyalahgunaan freedom of speech. Freedom of speech ini berasal dari Negara yang memiliki sistem liberal yang menyalahkan apabila seseorang memiliki peran setiap individu pada kelompok dapat memberikan pendapat, menyudutkan individu lain, memuji seseorang dengan tidak adanya batasan tertentu (Floridi, 2010).

Perkembangan media sosial kini yang tidak memiliki batasan waktu dan teritorial, setiap budaya dan tradisi tidak akan memiliki fungsi dalam perihal membatasi perluasan informasi. Berawal dari samarnya tradisi, hak freedom of speech banyak yang menyalah gunakan untuk membuat informasi bernuansa hoax bertujuan untuk membuat sensasi di media sosial. Bahkan unsur kesengajaan agar pengguna media sosial dapat melihat website sang perancang hoax agar dapat menikmati keuntungan dari pengunjung website-nya.

Hasil penelitian lain juga memperlihatkan tingkah laku pengguna media sosial paham terhadap informasi hoax, alasan, dampak, cara mengatasi serta cara tanggung jawab dalam penyebaran informasi hoax. Menurut pandangan psikologis, ada dua faktor yang menyebabkan pengguna cenderung mudah mempercayai pada informasi hoax. Pada dasarnya perilaku pengguna lebih cenderung percaya informasi hoax, jika informasi sesuai dengan opini atau perilaku yang dimiliki (Respati, 2017). Hasil penelitian juga mendukung pendapat David Harley dalam buku Common Hoaxes and Chain Letters (Harley, 2008), yang mengidentifikasikan hoax secara umum. Pertama, informasi hoax biasanya memiliki karakteristik surat berantai dengan menyertakan kalimat seperti "Sebarkan ini ke semua orang yang Anda tahu, jika tidak, sesuatu yang tidak menyenangkan akan terjadi". Kedua, informasi hoax biasanya tidak menyertakan tanggal kejadian atau tidak memiliki tanggal yang realistis atau bisa diverifikasi, misalnya "kemarin" atau "dikeluarkan oleh..." pernyataan-pernyataan yang tidak menunjukkan sebuah kejelasan. Kemudian yang ketiga, informasi hoax biasanya tidak memiliki tanggal kadaluwarsa pada peringatan informasi, meskipun sebenarnya kehadiran tanggal tersebut juga tidak akan membuktikan apa-apa, tetapi dapat menimbulkan efek keresahan yang berkepanjangan. Keempat, tidak ada organisasi yang dapat diidentifikasi yang dikutip sebagai sumber informasi atau menyertakan organisasi tetapi biasanya tidak terkait dengan informasi.

Perasaan positif akan timbul dalam diri seseorang jika opini atau keyakinannya mendapat pengakuan dan cenderung tidak akan mempedulikan apakah informasi yang diterimanya benar atau salah. Mereka akan untuk menyebarkan kembali informasi tersebut tanpa ada filter. 
Kondisi ini diperparah jika si penyebar informasi hoax memiliki pengetahuan yang kurang dalam memanfaatkan internet. Kecendrungan terlalu lama menggunakan internet untuk mencari informasi sehingga dimungkinkan akan mengalami information overload. Sehingga kerapkali terjadi informasi Hoax mudah mereka terima dan disebarkan kepada pihak lain tanpa terlebih dahulu melihat manfaat dan tidaknya bagi orang lain. Kecendrungan lainya, perilaku pengguna hanya melihat judul berita (head line) tanpa melihat isi dari berita tersebut dan mereka langsung berpendapat bahwa informasi tersebut sudah benar. Apalagi didukung orang mengirim informasi tersebut dari teman yang dipercaya atau dari media yang kredibel, sehingga langsung memberi komentar berdasarkan judul berita. Disisi lain ada ada gejala orang di media sosial untuk ikut memberikan komentar pada suatu tema agar bisa dianggap mengerti. Sebuah berita yang menjadi trending topik atau viral di media punya kecenderungan disebarkan lebih banyak, tanpa adanya upaya verifikasi terlebih dahulu, agar tidak terlihat ketinggalan. Dengan menyebarkan satu berita yang ramai dibicarakan orang bisa merasa tahu dan dianggap punya legitimasi sebagai orang yang berpengetahuan luas.

Perilaku penyebaran hoax melalui media sosial sangat dipengaruhi oleh pembuat berita baik itu individu maupun berkelompok, dari yang berpendidikan rendah sampai yang tinggi, dan terstruktur rapi. Lazonder menunjukkan bahwa terdapat perbedaan antara seseorang yang memiliki keahlian khusus dalam menggunakan search engine dengan orang yang masih baru atau awam dalam menggunakan search engine. Pengguna yang memiliki pengalaman lebih banyak dalam memanfaatkan search engine, akan cenderung lebih sistematis dalam melakukan penelusuran dibandingkan dengan yang masih minim pengalaman (novice) (Lazonder, Biemans, \& Wopereis, 2000).

Informasi Hoax sering disebarluaskan dan bersumber dari kabar bohong dan dibuat dalam satu jaringan sosial untuk menjaga kepentingan pribadi maupun kelompok. Seringkali secara sadar pengguna media sosial menyebarkan kebohongan untuk membantu agenda yang direncanakan. Penyebar Hoax bisa dari kalangan personal, komunitas, koorporasi, lembaga negara, dan militer kerap membuat propaganda kebohongan agar kepentingan mereka bisa terjaga. Informasi Hoax dibuat agar khalayak ramai tak lagi fokus pada masalah sebenarnya dan selanjutnya akan terjebak pada hal-hal bombastis yang bukan jadi permasalahan pokok. Posisi penyebar informasi Hoax yang dianggap kredibel menjadikan pengguna merasa yakin bahwa informasi itu benar dan menjadikan itu suatu kebenaran dan dapat disebarluaskan tanpa diperiksa kembali.

Pada dasarnya setiap pribadi memiliki tanggungjawab terhadap informasi yang mereka terima. Perilaku pengguna sosial media memiliki perasaaan emosional ketika memperoleh kabar buruk atau kabar tragedi seseorang dan merasa punya tanggung jawab moral untuk berbagi. Saat itu tidak lagi mempedulikan apakah itu hoax atau tidak?. Di media sosial, orang merasa punya beban untuk berbagi penderitaan agar bisa menjadi pelajaran bagi pengguna lain ataupun ingin melepaskan beban agar merasa lebih baik. Pengguna menginginkan komentar ataupun like dan seringkali dibagikan tanpa ada verifikasi terlebih dahulu Kebiasaan perilaku pengguna media sosial untuk tidak mau dipersalahkan apabila informasi tersebut Hoax, mereka menambahkan kata-kata "dari grup sebelah" sebagai tindakan preventif agar jika berita itu bohong. Perilaku ini merupakan upaya lepas tangan dari tanggung jawab kebenaran. Informasi dari broadcast sangat susah diverifikasi dan dilacak siapa penyebar awalnya.

\section{Upaya Media Lembaga Dakwah NU dalam Mencegah Berita Hoax}

Peran Lembaga Dakwah Nahdlatul Ulama dalam menyikapi berita hoax telah mendapatkan dukungan dari berbagai kalangan. Diantaranya adalah Wakil Presiden Republik Indonesia Prof. Dr. (H.C). K.H. Ma'ruf Amin,dan Ketua Umum Pengurus Besar Nahdlatul Ulama Prof. Dr. K.H. Said Aqil Siroj, M.A. Wakil Presiden Ma'ruf Amin menyatakan dukungan dan mearasa senang karena LDNU membuat program 34 ribu Da'i di media sosial. Ma'aruf Amin 
manganggap program tersebut dapat mencegah dan melawan hoax (Detik.com, 2019). Tidak hanya itu, Ketua Umum PBNU K.H. Said Aqil Siraoj mengatakan menangkal fitnah, hoax, caci maki kepada orang-orang yang tidak bersalah adalaha tugas keagamaan. Warga NU yang memiliki ilmu mumpuni tidak boleh diam, ketika kondisi baik-baik saja maka boleh diam (tawadlu), akan tetapi ketika hoax ada maka harus meluruskan (Dakwahnu.id, 2020).

Dalam pencegahannya Lembaga Dakwah NU aktif dalam bermedia sosial dengan menebarkan berita dan informasi yang bernuansa nasihat kepada khalayak. Sebagai contoh pencegahan berita hoax Lembaga Dakwah NU selalu menghimbau kepada seluruh masyarakat dalam menggunakan media sosial agar tidak terjadi perpecahan dan permusuhan. Terlebih menyebarkan berita hoax bukan perilaku yang tidak menunjukkan kepada kebaikan. Penerapan komunikasi yang terjadi hanya menggiring emosional masyarakat. Dalam Jurnalisme Positif memahami objektivitas, kebenaran sebuah informasi bisa didapatkan apabila media massa objektif. Kesamaan bukanlah hal yang menunjukkan keadilan, kecuali proporsionlitas (Berita Satu, 2012).

Sentuhan media baru mendapatkan perhatian yang cukup besar karena memiliki kelebihan yang dimiliki, halnya menyebarkan informasi dengan waktu yang relaitf cepat. Dengan memanfaatkan media berupa audio, meringkas pesan-pesan menjadi semenarik mungkin. Sehingga dia dapat diakses dimana saja dan kapan saja. Walaupun demikian tetap saja memiliki kekurangan dan kelebihan masing-masing (Kamarudin, 2015). Dalam tujuannya Lembaga Dakwah NU menangkal Hoax tidaklah mudah justru Lembaga yang bernaung pada sala satu Ormas Islam terbesar di Indonesia ini justru mendapati berita tidak benar yang ditujukan kepada NU.
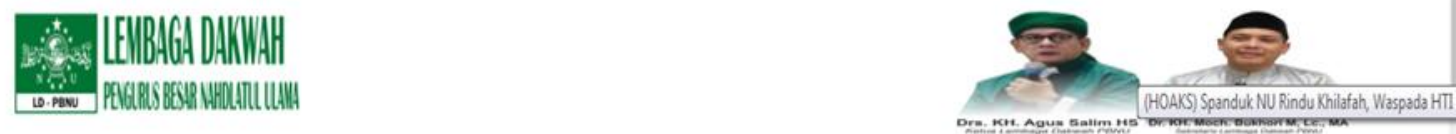

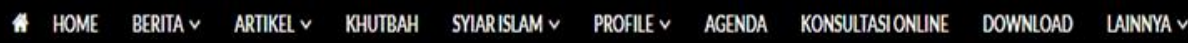

Home - Nasional - HOAKS) SpandukNU Rindu Khilafah, Wasspada HTI!

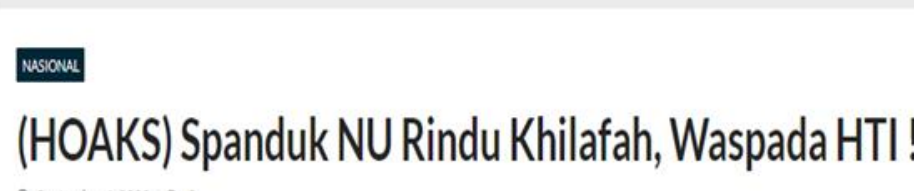

Search...

Q

0 September 6,2020 as 0

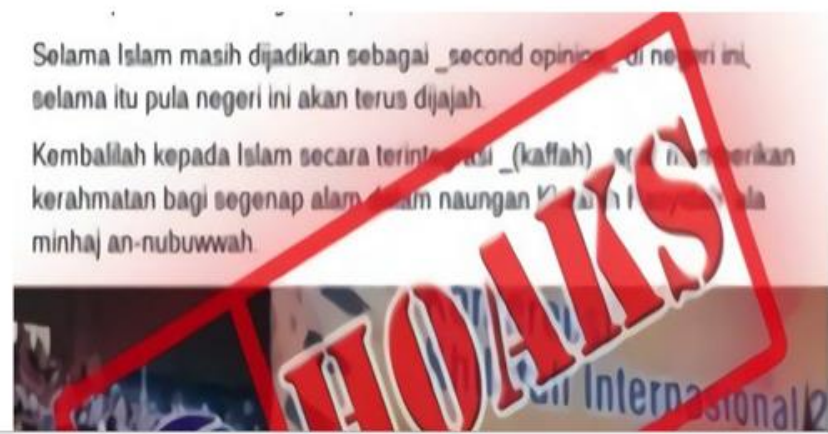

Trending Posts

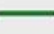

Sugi Nur-Refly Harun, Bukti 'Suul Adab' Paling Konkret! GP Ansor Siap Tindak Tegas

October 20,2020

Ramai Polemik UUCiptaker, Wapres Berikan 2Saran ke PBNU

October 17,2020

Jokowi Utus Mensesneg Serahkan Draf UU Ciptaker ke PBNU

Gambar 1. Hoaks Spanduk NU Rindu Khilafah, Waspada HTI 


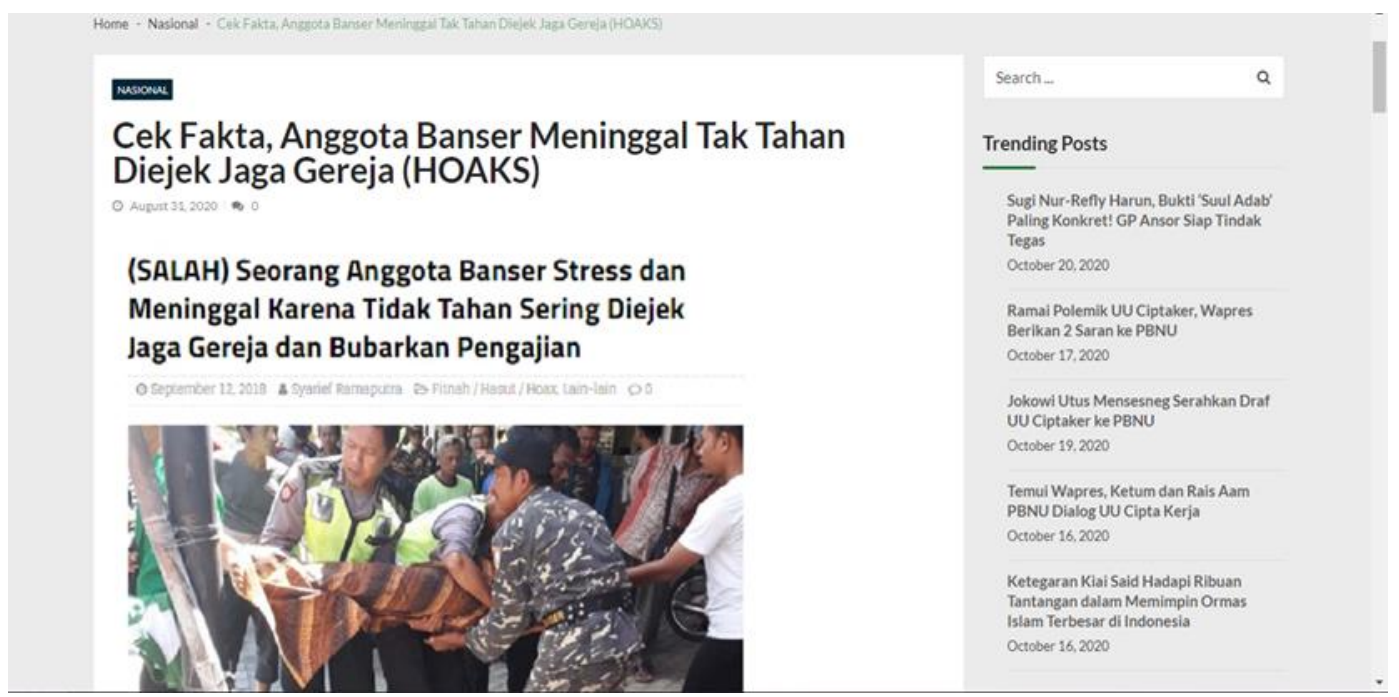

Gambar 2. Cek Fakta, Anggota Banser Meninggal Tak Tahan Diejek Jaga Gereja (HOAKS)

Gambar nomor 1 dilansir oleh dakwahnu.id mengenai jejak khilafah dengan membentangkan spanduk yang bertuliskan "Warga Nahdliyah Rindu Khilafah"pada tahun 2003 jauh sebelum KH. Said Aqil Siroj menjadi pimpinan PBNU. Akan tetapi setelah gambar tersebut dilacak dan diperiksa oleh trunbackhoax.id pada tahun 2019 menjelaskan bahwa gambar tersebut diambil pada agustus 2007. Acar itu memang benar diselenggarakan oleh HTI. Ismail Yusanto mengatakan turut mengundang KH. Zainuddin MZ, Amin Rais dan peserta dari luar negeri. Pendapat lain H. Helmy Faizal Zaini selaku Sekjen PBNU dalam konfirmasinya menegaskan bahwa spanduk tersebut hanya mencatut warga NU bukan resmi keluaran NU. Dari beberapa fakta ini klaim bahwa spanduk yang bertuliskan "Warga Nahdliyah Rindu Khilafah" adalah salah karena memang tidak resmi dan bukan keluaran NU.

Selanjutnya Gambar nomor 2 menunjukkan judul "Seorang Anggota Banser Stress dan Meninggal Karena Tidak Tahan Sering Diejek Jaga Gereja dan Bubarkan Pengajian" Narasi ini beredar di media sosial pada akun Alang Saputra (fb.com/dadang.akhmadsadly) berita ini dimuat pada 7 September 2018 pukul 16.23 WIB. Berdasarkan hasil cek fakta dari turnbackhoax.id. menyatakan fakta sebenarnya perihal berita tersebut. Faktanya foto lama yang dipakai lagi untuk membuat hoax, sedangkan faklta dilapangan menunjukkan bahwa adanya anggota banser yang meninggal karena kecelakaan bukan yang tertera pada judul berita salah tersebut. Lembaga Dakwah NU mengaktegorikan berita palsu/manipulasi atau biasa disebuut berita hoax.

Kita sadari kebebasan informasi haruslah dipilih dengan baik serta bijaksana dan tidak melanggar norma tertentu dalam kehidupan sosial (Hana, Januanti, Dkk, 2019). Dari dua contoh masalah diatas, Lembaga Dakwah NU mengupayakan agar pelaksanakaan pencegahan hoax ini harus dipersempit dari dunia maya. Dalam upayanya LDNU memiliki berbagai macam media sosial seperti instagram ldnu1926, twiter@ldnu1926, facebook Lembaga Dakwah PBNU, dan lama website dakwahnu.id. Dalam upaya ini kebijaksanaan pengguan media sosial menjadi sifat terpenting dalam tatanan berkomunikasi melalui media. Dampak boax merusak dasar komunikasi dan norma kehidupan dimedia sosial.

Masyarakat atau siapapun pengguna komunikasi online yang disebutkan di CMC Interactivity Model berhak mengirimkan dan menerima pesan sebagai komunikator dan komunikan. Dalam kasus ini pengguna yang berperan sebagai pengirim pesan adalah penyebar berita hoax. Lalu penerima pesan ini pengguna akun dan secara disebarkan secara publik. Kedua contoh ini dapat gambarkan bahwa kedua berita tersebut memiliki keinginan dan pemaksaan dengan menyamakan perilaku identitas organisasi. Keinginan yang lain agar 
masyarakat lebih percaya terhadap berita bohong yang telah dibuat sehingga timbullah rasa kebencian. Hal ini dapat dilihat di dunia maya secara aktif menggunakan, menyebarkan hoax, dan memberikan komentar negatif.

Terlepas dari kedua permasalahan diatas, upaya secara pandangan komunikasi pencegahan hoax oleh Lembaga Dakwah NU dapat dilihat dari berberapa sudut pandang:

1. LDNU membuat akun media sosial instagram, facebook, twiter, dan website guna menjaga pesan yang disampaikan oleh berbagai media jika ada indikasi hoax. Pesan komunikator kepada komunikan harus sesuai dan tidak ada kecacatan berita, apalagi berita bohong.

2. LDNU bekerjasama dengann TVRI, dan website turnbackhoax.id yang dikelola MAFINDO, MAFINDO merupakan kepanjangan dari Masyarakat Anti Fitnah Indonesia. Relawan ini organisasi perkumpulan resmi yang didirikan pada tanggal 19 November 2016, Akta Notaris Nomor 1 Tanggal 19 November 2016 yang dibuat oleh Isma Januarti, SH., M.KN. LDNU bekerjasama dengn TVRI dengan tujuan agar mempersempit ruang gerak fitnah dan hoax.

3. LDNU tetap menggunakan dasar Undang-Undang ITE sebagai pedoman dalam penggunaan media sosial.

Disisi lain kode etik, Undang-Undang ITE, dan budaya internet tidak seimbang. Karena penggunaan dengan pemahaman pedoman masih belum seimbang pada budaya penggunaan media sosial. Sehingga rentan terjadi pergesekan di medi sosial, maka selain 3 upaya yang digunakan oleh LDNU terdapat beberapa prinsip agar tidak membuat dan dapat terhindar dari hoax serta etika bermedia sosial selalu terjaga. Para pengguna media sosial perlu diberikan petunjuk melalui beberapa prinsip ini dengan memberikan pengertian dan pemahaman pedoman penggunaan media sosial.

Penggunaan etika ini baik di dunia internet dan dunia nyata tidak memiliki perbedaan yang sangat jelas. Artinya kedua saling memiliki porsi sama dalam mewujudkan komunikasi yang berkualitas tanpa adanya kerugian dari pihak lain. Maka perlulah dibangun prinsip agar alur komunikasi, baik posisi sebagai pemberi pesan dan penerima pesan tidak ada goresan yang rusak dan roh komunikasi itu sendiri tetap terjaga. Seperti yang dijelaskan oleh Ratna Istriyani dan Nur Huda Widiana dalam Etika Komunikasi Islam dalam membendung Informasi hoax di ranah publik maya (Istriyani \& Widiana, 2016). Beberapa prinsip tersebut adalah:

\section{Prinsip Kejujuran}

Lidah tak bertulang sebuah pepatah untuk meyakinkan agar kita semua memiliki sifat kehati-hatian dalam berinterkasi. Karenanya tak sedikit permasalahan berawal dari kebohongan atau ketidakjujuran. Dianatara bentuk kejujuran dalam berkomunikasi adalah tidak mengalihkan fakta dan tidak berdusta.

\section{Prinsip Kebersihan}

Aspek apapun dalam dunia, baik lingkungan sekitar dan jiwa diri sendiri tidak bisa lepas dari kebersihan. Termasuk kebersihan dalam menyampaikan pesan. Pesan yang baik maka akan timbul hal yang baik. Begitu pula sebaliknya jika pesan di desain untuk mengadu domba, saling membenci, jorok, provokatif, semua ini mencerminkan bahwa jiwa sedang tidak bersih.

\section{Prinsip Berkata Positif}

Pesan dalam alur komunikasi yang positif tentunya akan membuat seseorang nyaman dengan kondisi apapun. Seorang komunikator membuat pesan positif dan sering dikirim kepada komunikan, tentunya komunikan akan menyimpan modal informasi secara nyaman dari pesan-pesan yang positif. 


\section{Prinsip Pengawasan}

Media sosial tidak serta merta hanya diawasi oleh pengguna lain, namun pihak yang memiliki otoritas sebagai aktor utama dalam menjamin kemananan berita menjadi pengawas utama. Tidak hanya itu pengguna jauh lebih penting untuk menjaga kondusifitas dalam bermedia sosial. Karena tidak semua dari media sosial bisa dipercayai.

\section{Prinsip Selektifitas dan Validitas}

Memberikan pesan yang akurat merupakan pengguna media yang berkualitas. Selain kridibilitas informasi yang akurat dapat menjauhkan kita dari perpecahan dan semakin bijak dalam menggunakan media sosial.

\section{Prinsip Saling Memengaruhi}

Dalam kehidupan kita dasar komunikasi adalah saling memengaruhi, maka membangun komunikasi yang sehat adalah bagian yang tidak bisa dipisahkan dari fungsi interaksi itu sendiri. Pengaruh ini tidak hanya sesaat terkadang akan selamanya dikenang oleh pengguna media sosial yang lain.

\section{Prinsip Keseimbangan Berita}

Informasi yang berimbang membuat kandungan pesan berita semakin akurat. Prinsip ini merupakan sebuah keharusan agar perlakuan adil kepada objek berita dapat dikatakan informasi berimbang.

\section{Prinsip Kepribadian}

Perlu disadari bahwa tidak semua hal bisa dipublikasikan, terdapat kerahasiaan yang harus dijaga. Hal ini menunjukkan bahwa sifat hati nurani tidak dimiliki oleh dunia maya. Akan tetapi pengguna dunia maya ini lah yang harus sadar bahwa nilai-nilai kemanusiaan/ adab harus dijunjung, tidak ada kebohongan, adu domba, penyebar kebencian berkeliaran di dunia maya. Jadi tidak semuanya persoalan pribadi dapat diungkapkan diranah publik.

Eksisntensi dari beberap prinsip diatas dalam pandangan komunnikasi inilah harus disebarluaskan sebagai bagian dari pencegahan hoax. Kelompok kecil yang dimiliki dapat menjadi peran utama sebagai landasan dalam menjalin komunikasi dan bermedia sosial. Dengan tujuan membentuk tanggungjawab dari diri sendiri agar tida adanya perpecahan yang dihasilkan dari hoax. Sehingga ketika menyebarkan informasi tidak berlandaskan dari berita bohong, namun tetap mengedepankan rasa kehati-hatian dalam menyebarkn informasi sehingga komunikasi memiliki akurasi dan berkualitas.

\section{PENUTUP}

Melaksanakan aktivitas komunikasi pada masyarakat maya harus dipahami bahwa tidak ada perbedaan dengan dunia nyata. Terdapat esensi nilai yang diakandung ketika menyampaikan pesan. Pertanyaan-pertanyaan who says, what and with channel to whom with what effect, (siapa yang mengatakan, apa dengan saluran apa, kepada siapa, dengan pengaruh bagaimana). Tidak hanya siapa pemberi pesan dan siapa penerima pesan akan tetapi dampak dari pesan itu sendiri yang menjadi pengaruh kuat dalam merubah situasi khalayak. Maraknya hoax menjadi pelajaran bagi siapapun untuk mencegahnya.

Tujuan dari ini semua adalah terciptanya komunikasi yang faktual sesuai dengan prinsip sosial, tidak adanya unsur kebohongan caci maki, ujaran kebencian, serta peran pemerintah dan ormas yang saling mendukung satu sama lain untuk melawan boax. Menjunjung tinggi nilai-nilai kepribadian, berperilaku positif menjadi dasar untuk membentengi diri tidak membuat hoax. Berawal mewujudkan komunikasi yang harmonis tanpa hoax. Upaya membangun persepsi 
masyarakat terlihat jelas bahwa dasar sifat kejujuran haru dimiliki oleh setiap pribadi. Salah satu yang tidak bisak kita tinggalkan juga adalah memvalidasi kepastian dan kebenaran informasi yang kita terima dengan sumber-sumber lainya. Apakah kita mendapatkan berita yang baik ataukah sebaliknya yang justru memicu kebohongan dan akhirnya saling membenci.

\section{DAFTAR PUSTAKA}

Ali, M. (2017). Antara komunikasi, Budaya dan Hoax. In Melawan Hoax di Media Social dan Media Massa. ASKOPIS PRESS.

Alif, M. I., Hardian, A., Kurniawan, F., Triartanto, A. Y., \& Suriyanto, A. D. (2018). Literasi Media Dalam Menanggulangi Berita Hoax (Studi Pada Pelajar SMKN 4 Bekasi dan Mahasiswa AKOM BSI, Jakarta). Jurnal Abdimas BSI: Jurnal Pengabdian Kepada Masyarakat, 1(3), 416-423. doi: 10.31294/JABDIMAS.V1I3.4052

Holding Media. (2012). Jurnalisme Positif. Jakarta: Berita Satu

Dakwahnu.id. (2020). K.H. Said Aqil Siradj Warga dan Santri NU Jangan Diam, Harus Kuasai Media Massa. 28 September 2020

Detik.com. (n.d.). Ma'ruf Amin Minta Da’i Medsos LDNU Tangkal Hoax dan Radikalsime. diakses 20 oktober 2020

Floridi, L. (2010). The Cambridge Handbook of Information and Computer Ethics. Cambridge: Cambridge University Press.

Hana, N., Januanti, A. R., \& Dkk. (2019). Komunikasi dan Media Sosial. Makasar: Universitas Muslim Indonesia.

Harley, D. (2008). Common Hoaxes and Chain Letters. San Diego: ESET, LLC.

Istriyani, R., \& Widiana, N. H. (2016). Etika Komunikasi Islam dalam Membendung Informasi Hoax di Ranah Publik Maya. Jurnal Ilmu Dakwah, 36(2), 288-315.

Juditha, C. (2018). Hoax Communication Interactivity in Social Media and Anticipation (Interaksi Komunikasi Hoax di Media Sosial serta Antisipasinya). Journal Pekommas, 3(1), 31. doi: $10.30818 /$ jpkm.2018.2030104

Juliswara, V. (2017). Mengembangkan Model Literasi Media yang Berkebhinnekaan dalam Menganalisis Informasi Berita Palsu (Hoax) di Media Sosial. Jurnal Pemikiran Sosiologi, 4(2), 142. doi: $10.22146 /$ jps.v4i2.28586

Kamarudin. (2015). Komunkasi Politik. Lhokseumawe: Univeristas Malikus Shaleh.

Lazonder, A., Biemans, H., \& Wopereis, I. (2000). Differences between novice and experienced users in searching information on the World Wide Web. Journal-American Society for Information Science, 51(6), 576-581. doi: https://doi.org/10.1002/(sici)10974571(2000)51:63.0.co;2- 7

Mulyana, D. (2010). Ilmu Komunikasi Suatu Pengantar. Bandung: PT. Remaja Rosdakarya.

Respati, S. (2017). Mengapa Banyak Orang Mudah Percaya Berita "Hoax"? Halaman all Kompas.com. Retrieved December 28, 2021, from https://nasional.kompas.com/read/2017/01/23/18181951/mengapa.banyak.orang.mud ah.percaya.berita.hoax.?page $=$ all

Ridwan, A. (2016). Komunikasi Antarbudaya (mengubah Persepsi dan Sikap dalam Meningkatkan Kreativitas Manusia). Bandung: Pustaka Setia. 
Tarigan, A. (2017). Menko Polhukam: berita "hoax" buat masyarakat merugi - ANTARA News. Retrieved December 28, 2021, from https://www.antaranews.com/berita/604730/menko-polhukam-berita-hoax-buatmasyarakat-merugi

W, B., \& A, R. (2008). Trends in Internet Information Behavior: 2000- 2004.

Ya’qub, H. (1998). Etika Islam. Bandung: Diponegoro. 